\title{
SEROTONERGIC REGULATION \\ OF THE BUCCAL (FEEDING) RHYTHM OF THE POND SNAIL, LYMNAEA STAGNALIS. AN IMMUNOCYTOCHEMICAL, BIOCHEMICAL AND PHARMACOLOGICAL APPROACH
}

\author{
Károly Elekes, ${ }^{1 *}$ LÁszló Hiripi, ${ }^{1}$ Gábor Balog, ${ }^{1}$ Gábor MaÁsz, ${ }^{1}$ \\ IZABElla Battonyai, ${ }^{1}$ Marina Yu. Khabarova, ${ }^{2}$ \\ RÉKa HoRVÁth ${ }^{1}$ and Elena E. VORONEZHSKAYA ${ }^{2}$ \\ ${ }^{1}$ Department of Experimental Zoology, Balaton Limnological Institute, MTA Centre for Ecological \\ Research, Hungarian Academy of Sciences, H-8237 Tihany, Hungary \\ ${ }^{2}$ Institute of Developmental Biology, Russian Academy of Sciences, Moscow 119334, Russia
}

(Received: May 28, 2018; accepted: June 29, 2018)

\begin{abstract}
Hatching is an important phase of the development of pulmonate gastropods followed by the adult-like extracapsular foraging life. Right before hatching the juveniles start to display a rhythmic radula movement, executed by the buccal complex, consisting of the buccal musculature (mass) and a pair of the buccal ganglia. In order to have a detailed insight into this process, we investigated the serotonergic regulation of the buccal (feeding) rhythm in $100 \%$ stage embryos of the pond snail, Lymnaea stagnalis, applying quantitative immunohistochemistry combined with the pharmacological manipulation of the serotonin (5-HT) synthesis, by either stimulating (by the 5-HT precursor 5-hydroxytryptophan, 5-HTP) or inhibiting (by the 5-HT synthesis blocker para-chlorophenylalanine, pCPA) it. Corresponding to the direction of the drug effect, significant changes of the fluorescence intensity could be detected both in the cerebral ganglia and the buccal complex. HPLC-MS assay demonstrated that 5-HTP increased meanwhile pCPA decreased the 5-HT content both of the central ganglia and the buccal complex. As to the feeding activity, 5-HTP induced only a slight (20\%) increase, whereas the pCPA resulted in a $20 \%$ decrease of the radula protrusion frequency. Inhibition of 5-HT re-uptake by clomipramine reduced the frequency by $75 \%$. The results prove the role of both central and peripheral 5-HTergic processes in the regulation of feeding activity. Application of specific receptor agonists and antagonists revealed that activation of a 5 - $\mathrm{HT}_{1}$-like receptor depressed the feeding activity, meanwhile activation of a 5- $\mathrm{HT}_{6,7}$-like receptor enhanced it. Saturation binding plot of $\left[{ }^{3} \mathrm{H}\right]-5-\mathrm{HT}$ to receptor and binding experiments performed on membrane pellets prepared from the buccal mass indicated the presence of a 5 - $\mathrm{HT}_{6}$-like receptor positively coupled to cAMP. The results suggest that 5-HT influences the buccal (feeding) rhythmic activity in two ways: an inhibitory action is probably exerted via 5 - $\mathrm{HT}_{1}$-like receptors, while an excitatory action is realized through $5-\mathrm{HT}_{6,7}$-like receptors.
\end{abstract}

Keywords: 5-HT - feeding activity - buccal mass innervation - immunohistochemistry - pharmacology - receptors

\footnotetext{
*Corresponding author; e-mail address: elekes.karoly@okologia.mta.hu
} 


\section{INTRODUCTION}

Invertebrate models have successfully been used for the elucidation of the neuronal background of behavioral phenomena. Among these models are, for example, the crustacean stomatogastric system [21, 40, 47], the insect thoracic motor system [7], the gastropod respiratory [50], locomotor [51] and feeding [6,13,14] networks, or the gill withdrawal reflex [20]. In gastropods, however, considerably less attention has been paid to the peripheral targets connected to these central events, such as, for example, the coordinated muscle contraction, executing the radula movement, in response to various signal molecules (transmitters, neuromodulators and neurohormones), or their receptors that mediate their effect.

Among the regulatory substances serotonin (5-HT) has been considered as one of the major neuromodulators in invertebrates. Its role in a number of physiological and behavioral processes has well been established $[1,10,19,23,35,61]$, including a pivotal role in the regulation of the feeding behavior of gastropods $[8,18]$. In connection with a diverse set of feeding functions the role of 5-HT was addressed including the sensory initiation of feeding [41], central motor pattern generation [11, 12, 49], as well as the cellular mechanisms underlying different forms of feeding related behavior, such as arousal [29], satiety, [30] and learning [3,26]. While it is generally accepted that 5-HT modulates the feeding system at central levels (cerebral and buccal ganglia), there is considerably less information on its presence and role at the periphery, related to the buccal mass executing the cyclic movement of the radula during feeding in Lymnaea [4, 15].

The key member of the central feeding network is the giant cerebral 5-HTergic neuron (CGC - Lymnaea, MGC - Helix, MCC/C1 - Aplysia; [44, 59; see also 8, 39]. Fibers from this cell project through the cerebro-buccal connectives to the buccal ganglia and then via the peripheral nerves to the head region, thus participating in the modulation of the entire feeding system $[4,6,38,60]$.

5-HT acts through multiple receptors to mediate a great variety of functions in vertebrates and invertebrates [5, 42, 52]. Identification of 5-HT receptor subtypes has begun over 50 years ago when Gaddum and Picarelli [16] described two types of physiological actions of 5-HT which could be blocked by different antagonists. Later a number of studies provided additional functional evidence for the existence of more than one 5-HT receptor type, and this idea was confirmed following the emergence of radio-ligand binding techniques as well. In invertebrates 5-HT was shown that a number of effects influencing different functions in the central nervous system (CNS) and periphery mediated by 5 -HT were likely to be transmitted by a multitude of receptor subtypes [see e.g. 18, 43, 53, 57].

In our present investigation we analyzed the 5-HTergic modulation of the feeding activity (buccal rhythm) of the pond snail, Lymnaea stagnalis, with special attention to the radula movements (protraction, rasping and retraction) at the end of the embryogenesis, right before hatching (100\% embryonic stage). The investigations were performed in three different directions. First, we have studied the organization of the 
central and buccal 5-HT-immunoreactive (IR) elements upon the effect of different pharmacological interventions, such as the inhibition and stimulation of 5-HT synthesis, accompanied by HPLC-MS assay to determine the 5-HT level. It was followed by the in vivo analysis of feeding activity (radula movements) after the pharmacological manipulation of the 5-HT level and different 5-HT receptors. Finally, biochemical-binding studies were also applied to characterize the 5-HT receptor types present in the buccal mass.

\section{MATERIALS AND METHODS}

\section{Animals and staging}

Populations of adult Lymnaea stagnalis L. were maintained in aquaria at $20-25{ }^{\circ} \mathrm{C}$ supplied with aerated filtered water from Lake Balaton (filtered Balaton-water, FBW) and fed on lettuce. Egg masses and P5, P6 juvenile snails were collected from laboratory culture. Embryonic development (8-10 days) was staged on the basis of a specific set of morphological, morphometric and behavioral features, according to Morrill [37] and Mescheriakov [36]. Stages were expressed as a percentage of total embryonic development, according to Marois and Croll [34], wherein 0\% (E0\%) corresponds to the first cleavage and $100 \%(\mathrm{E} 100 \%)$ to embryos right before hatching. Juvenile snails were categorized according to the shell size [9].

\section{Immunocytochemistry}

The immunohistochemical procedure applied for the visualization of 5-HTergic and muscle elements has been described in details elsewhere $[4,56]$. Briefly, embryos of $100 \%$ stage were removed from the egg capsules, were anesthetized on ice, and then the isolated buccal complex (buccal mass, including the buccal ganglia), as well as the circumesophageal ganglionic ring (CNS) were fixed in $4 \%$ paraformaldehyde diluted in $0.1 \mathrm{M}$ phosphate buffer (PB) for 4 hours at room temperature. After thorough washing in PB buffered saline (PBS), the whole mount specimens were incubated in mouse monoclonal anti-5-HT antiserum (Dako, Denmark, see also in Balog et al., 2012) diluted 1:2000 in PBS containing $2.5 \%$ normal goat serum, $0.25 \%$ bovine serum albumine and $5 \%$ Triton-X (TX) for 48 hours at $4{ }^{\circ} \mathrm{C}$. Following $3 \times 10 \mathrm{~min}$ washing in PBS the preparations were incubated in a mixture of goat-anti-rabbit Alexa 488-conjugated IgG (Molecular Probes, USA) and phalloidin conjugated with TRITC (Sigma-Aldrich), both diluted 1:800 in PBS-TX, for 12 hours at $4{ }^{\circ} \mathrm{C}$. After $3 \times 10$ min washing in PBS, the specimens were immersed in $70 \%$ glycerol diluted in PBS, mounted on glass slides and examined by a Leica TCS SPE or a Leica TCS SP5 confocal laser scanning microscope with appropriate wavelength-filter configuration settings. The specificity of the primary antibody has been proved previously [4]. 
For the quantitative measurement of the immunofluorescence intensity preparations were made using the same protocol as above and then scanned under the same microscope settings as above. This allowed to measure the relative brightness of 5-HT immunostaining in the central ganglia, focusing on the cerebral ones and the buccal complex. At least 25 embryos of $100 \%$ stage were examined both for control and after 5-HTP and pCPA treatments, respectively (5-HTP: $100 \mu \mathrm{M}$, $45 \mathrm{~min}, 6 \mathrm{~h}$; pCPA: $5 \mu \mathrm{M}, 6 \mathrm{~h}$ ). Series of $0.5 \mu \mathrm{m}$ optical sections were projected into single images and exported as TIFF images. Average brightness of corresponding areas in control and experimental preparations were measured using Image J software [43].

\section{Pharmacological analysis of the feeding rhythm}

To examine the effect of 5-HT and different 5-HTergic drugs on the feeding activity, $100 \%$ embryos were monitored inside the egg capsule. According to Voronezhskaya et al. (1999), regular radula protrusions can be observed first prior to hatching in $90-100 \%$ stage embryos. Individual egg capsules with embryos were separated randomly from the egg masses and placed into a small glass chamber containing $1 \mathrm{ml}$ FBW. After $10 \mathrm{~min}$ accommodation under shaded light the embryos were recorded for 10 minutes in a Zeiss Axioplan compound microscope attached with a MyScope $130 \mathrm{M}$ Camera (Webbers). The number of the radula protrusions was counted for one minute and the mean frequency was determined thereafter. The data obtained served as control. 5-HTergic drugs in 10 or $100 \mu \mathrm{M}$ concentration were thereafter added to the chamber and mixed with gentle pipetting. Following incubation for 15 and 45 minutes, respectively, a subsequent 10 min recording was made. During each 10 minutes of recording three times one min intervals were arbitrary chosen when the radula protrusions of individual embryos were counted. The mean value for each treatment was calculated on the basis of data obtained from a minimum of 15 embryos originating from at least two different egg masses.

In the course of the assays the following drugs were used: 5-HTP, clomipramine, pCPA, 5-carboxamidotryptamine (5-CT), 8-OH-DPAT, indorenate, metergoline, S-WAY100135, SB269970.

Statistical evaluation of the effects of different pharmacological treatments on the radula movement frequency was performed with two-way ANOVA with individuals being the other predictor factor followed by Tukey post-hoc test, using Statistica 6.0 (StatSoft, Inc.).

\section{Biochemistry}

\section{Determination of 5-HT by HPLC-MS}

Sample preparation. The buccal complex including the buccal ganglia and the buccal mass, and the cerebral ganglia, respectively, were prepared from both $100 \%$ control 
embryos as well as from those treated previously with 5-HTP (45 min and 6 h) or pCPA $(6 \mathrm{~h})$.

For extraction of 5-HT acetonitrile was applied containing $0.1 \%$ formic acid and $0.01 \mathrm{~m} / \mathrm{v} \%$ dithiotreitol. The $200 \mu \mathrm{l}$ extracting solution was added to 50 embryos. Thereafter the samples were homogenized and were explored with a high energy ultrasonicator UIS250V (Hielsher Ultrasound Technology) at $6 \times 10$ seconds, applying ice cooling between cycles. Samples were then vortex mixed and centrifuged (Heraeus Biofuge Pico, Thermo Fisher Scientific) at 10,000 rpm for 5 minutes. After it, spinning supernatants were loaded in pure tubes and the solvents were evaporated with a SpeedVac concentrator (Eppendorf Life Sciences) at room temperature. The samples were dissolved fourfold number of masses in ultra-pure water containing $0.1 \%$ formic acid and loaded into autosampler vials for HPLC-MS measurements.

5-HT measurement. Analyses were performed with a complex Ultimate 3000 (Dionex) micro HPLC system equipped with a quaternary pump, a degasser, and a QExactive UHR spectrometer (Thermo Fisher Scientific). Separations were performed on a Kinetex PFP column $(100 \mathrm{~mm} \times 2.1 \mathrm{~mm}$ i.d., particle size $2.6 \mu \mathrm{m}$, Phenomenex). The flow rate was $200 \mu \mathrm{l} / \mathrm{min}$, the injection volume was $5 \mu \mathrm{l}$, and the temperature was kept at $4{ }^{\circ} \mathrm{C}$ in the autosampler and $40{ }^{\circ} \mathrm{C}$ in the column compartment. Xcalibur (Thermo Fisher Scientific) software was used for controlling the instrument, data acquisition and spectrum evaluations. A Thermo Orbitrap mass spectrometer equipped with a HESI source was used for mass detection. The ionization source was operated with an endplate potential of $3 \mathrm{kV}$ in the positive ion mode.

For quantitative analysis of 5-HT five points calibration curves were made using $122 ; 305 ; 610 ; 1200 ; 2100 \mathrm{pmol} / \mathrm{ml} 5-\mathrm{HT}$ as standards. Correlation coefficients $\left(\mathrm{r}^{2}\right)$ were between 0.9956 and 0.9989 for all acceptable calibration curves both in MS and MS/MS mode. The limit of detection was $2.9 \mathrm{pmol} / \mathrm{ml}$ and the limit of quantification was $9.4 \mathrm{pmol} / \mathrm{ml}$ for $5-\mathrm{HT}$. 5-HT was identified by their exact molecular weight and by their fragments according to the literature data. The quantification of the data was made parallel both in MS and MS/MS mode. 5-HT was identified at $177.10 \mathrm{~m} / \mathrm{z}$ parent ion protonated form $\left[\mathrm{M}+\mathrm{H}^{+}\right]$and at $166.08 \mathrm{~m} / \mathrm{z}$ fragment ion protonated form $\left[\mathrm{F}+\mathrm{H}^{+}\right]$which were characterized by 3.9 min retention time. Based on these data, the identification of 5-HT in the samples were performed.

For the measurements three parallel groups of samples (buccal mass or CNS) of embryos of $100 \%$ stage, each consisting of 50 animals, were used.

\section{Ligand binding analysis}

Membrane pellet preparations from the buccal mass of P5-P6 snails were obtained and processed for the binding assay as described before [25]. Saturation and competition experiments were repeated three times. The results of kinetic and competition experiments were evaluated using the Grafit program [31]. For the inhibition of 
[ $\left.{ }^{3} \mathrm{H}\right]-5$-HT binding agonists (5-HT, 5-CT) and antagonists (Doxepine, SB258585) were applied in a concentration range between $1-100 \mu \mathrm{M}$.

\section{Cyclic adenosine monophosphate (cAMP) assay}

In the buccal mass of P5-P6 snails the adenylate cyclase activity was measured as cAMP accumulation in the tissue as a response to the application of 5-HT, or its agonists and antagonists, respectively. Following preparation, buccal masses were pre-incubated for $5 \mathrm{~min}$ in $250 \mu \mathrm{l}$ Lymnaea saline containing $0.5 \mathrm{mM}$ isobutylmethylxantine, $0.1 \mathrm{mM}$ guanosine-5-triphosphate and $0.5 \mathrm{mM}$ adenosine-5-triphosphate. 5-HT or agonists were added to the mixture and the incubation was continued for an additional $5 \mathrm{~min}$. The control experiments contained no 5-HT or other agonist. The agonists applied were 5-HT, 5-CT, 5-methoxytryptamine, 8-OH-DPAT. The inhibitory effect of the antagonists was investigated on activity of the adenylate cyclase stimulated by $100 \mu \mathrm{M} 5-\mathrm{HT}$. In these experiments the incubation mixture contained also the antagonists in a concentration of $10^{-7}-10^{-4}$. The antagonists were clozapine, SB258585, clomipramine, doxepine. The amount of cAMP was determined by the protein binding method using the Amersham cAMP $\left[{ }^{3} \mathrm{H}\right]$ assay Kit (GE Healthcare UK Limited) as described earlier [15]. Measurements were carried out four times.

\section{Chemicals}

All drugs used in the experiments were purchased from Sigma.

\section{RESULTS}

\section{Effect of changes of 5-HT synthesis on the 5-HTergic innervation in the CNS and the buccal complex}

Prior to the detailed functional analysis of the role of 5-HT in the regulation of buccal (feeding) rhythm, we have investigated the organization of the 5-HT-IR elements in the cerebral ganglia and the buccal complex after 5-HTP $(100 \mu \mathrm{M}, 45 \mathrm{~min}, 6 \mathrm{~h})$ and pCPA $(5 \mu \mathrm{M}, 6 \mathrm{~h})$ administration, respectively. The investigations included, on the one hand, qualitative (Fig. 1A-F) and, on the other, quantitative immunocytochemistry (Fig. 1G). Changes evoked by the drug administration were also correlated with HPLC-MS assays (Fig. 1H, I).

The immunocytochemical studies demonstrated that before hatching (100\% stage) 5-HT-IR elements were well distributed in the nervous system, including the cerebral 
ganglia (Fig. 1A) and the buccal complex (Fig. 1B). The cerebral ganglia contained labeled cells and a richly innervated neuropil, and the connectives and peripheral nerves were also supplied with labeled axons. Also, 5-HT-IR processes were seen throughout innervating the buccal mass (musculature).

Incubation with 5-HTP resulted in a clear, significant increase of the brightness of labeled fibers in the cerebral ganglia (and the entire CNS), reflected also by quantitative measurements (Fig. 1C, G). The number of peripheral processes innervating the buccal mass, their ramification and varicosities also increased, although this was only less supported by the quantification of the 5-HT-IR intensity of this region (Fig 1D, G). HPLC-MS assay of the 5-HT content of the buccal complex and the cerebral ganglia demonstrated a strong increase of 5-HT level both after $45 \mathrm{~min}$ (17-times) and after $6 \mathrm{~h}$ (47-times) of 5-HTP treatment, compared to the control (Fig. 1H).

Incubation with pCPA resulted in a slight (20\%) but significant decrease of fluorescence intensity of the 5-HT-IR elements in the cerebral ganglia (and in the entire CNS) and resulted in a twofold reduction of brightness in the innervation of buccal complex (Fig. 1E, F). HPLC-MS assay revealed a three times reduction of 5-HT content in the buccal complex compared to the control (Fig. 1I).

\section{Effect of 5-HTergic drugs on the buccal (feeding) rhythm}

In the next step we have investigated the action of selected drugs on the buccal rhythm (radula protraction), which affected either the 5-HT level or different 5-HT receptors. Figure 2A shows the time-lap frames of the various phases (resting, protraction, rasping, retraction) of the radula movement in living preparation at $100 \%$ stage. Application of 5-HT itself at 1 or $2 \mu \mathrm{M}$ concentrations activated the radula movement. However, it simultaneously strongly stimulated the ciliary locomotion (gliding) of the embryo on the inner surface of the egg capsule, thus making impossible to count reliably the number of the protractions. Therefore, instead of 5-HT, we used 5-HTP, its immediate precursor. Application of 5-HTP in both low $(10 \mu \mathrm{M})$ or high $(100 \mu \mathrm{M}) 5$-HTP concentration for $15 \mathrm{~min}$ or $45 \mathrm{~min}$ also affected the locomotion of the embryos; almost $100 \%$ of tested animals expressed gliding on the inner surface of the egg capsule accompanied with active left-right movements of the head, as well as occasional shell rotations and columellar muscle contraction. However, the intensity of these movements was never as strong as after 5-HT administration, hence the number of radula protrusions could be counted.

Application of $10 \mu \mathrm{M}$ 5-HTP for $15 \mathrm{~min}$ did not influence the buccal rhythm, but after $45 \mathrm{~min}$ it induced a significant decrease of the radula movement (57\% compared to the control, $\mathrm{n}=10$ ) (Fig. 2B). To the contrary, $100 \mu \mathrm{M} 5$-HTP slightly increased the number of radula protrusions $(21 \%, \mathrm{n}=21)$ after $15 \mathrm{~min}$, and this effect was the same after $45 \mathrm{~min}$ of incubation (Fig. 2B). Clomipramine $(5 \mu \mathrm{M})$, a 5 -HT re-uptake blocker and $5-\mathrm{HT}_{6}$ receptor antagonist depressed $(18 \%, \mathrm{n}=10)$ the frequency of the 

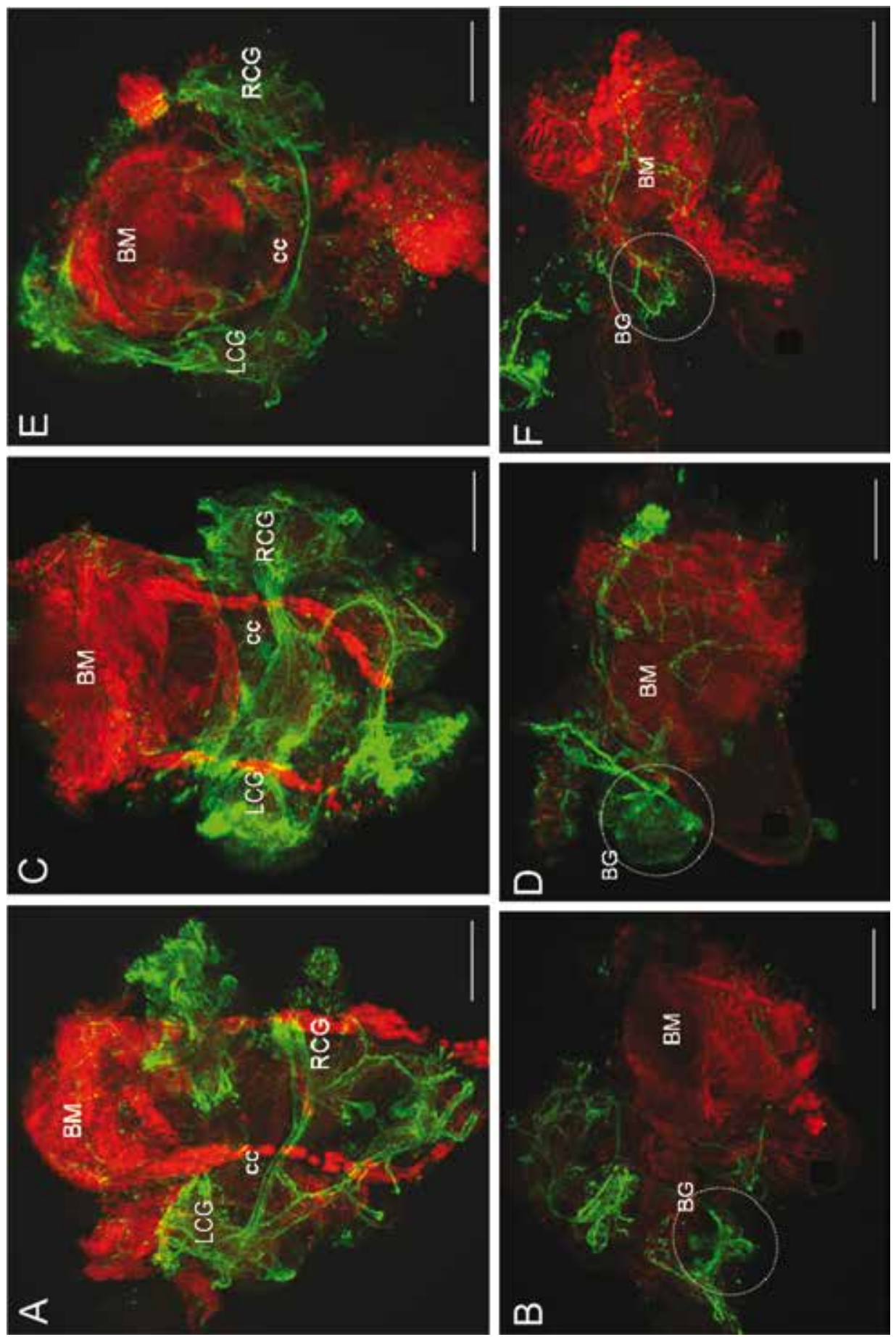

Acta Biologica Hungarica 69, 2018 


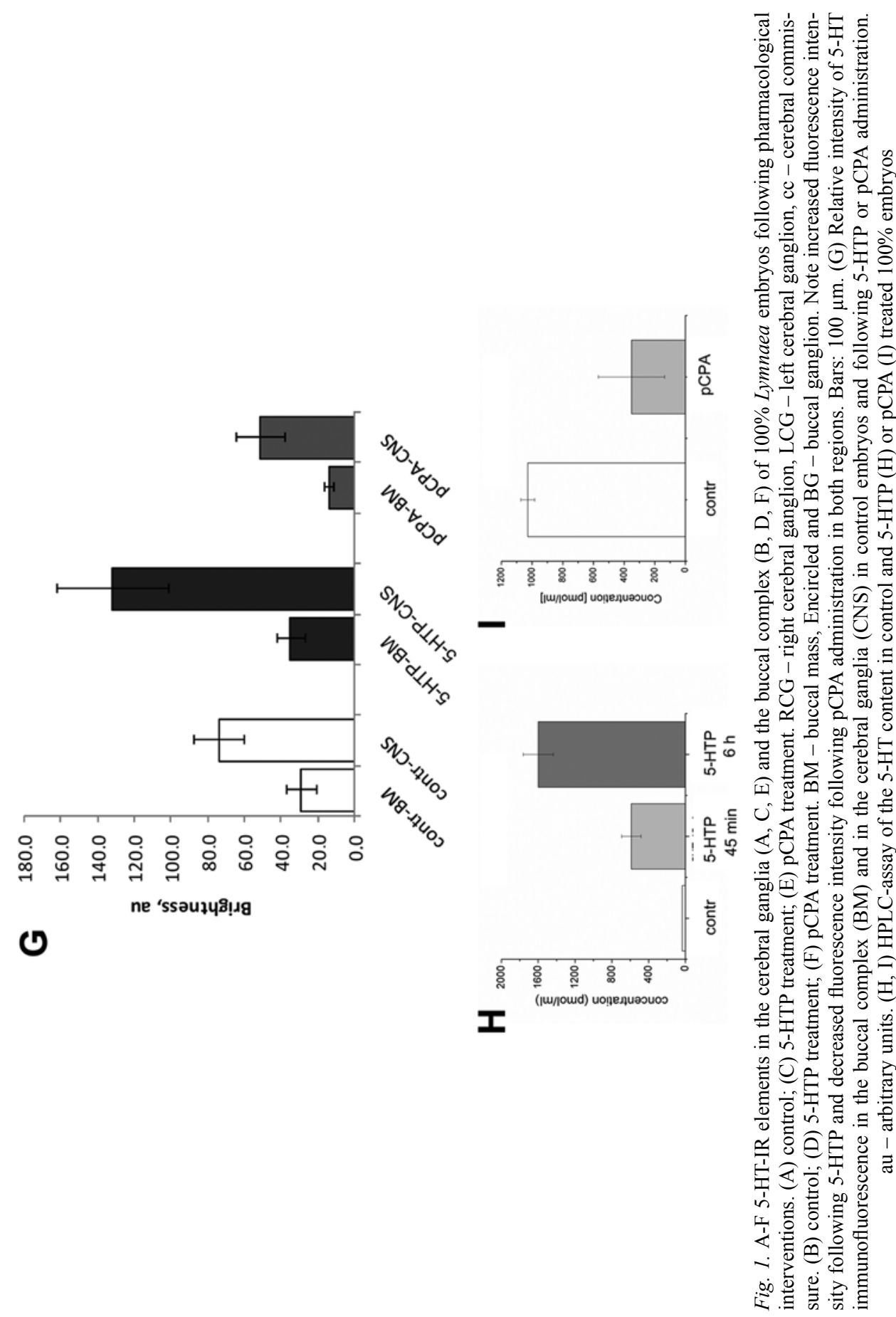

Acta Biologica Hungarica 69, 2018 

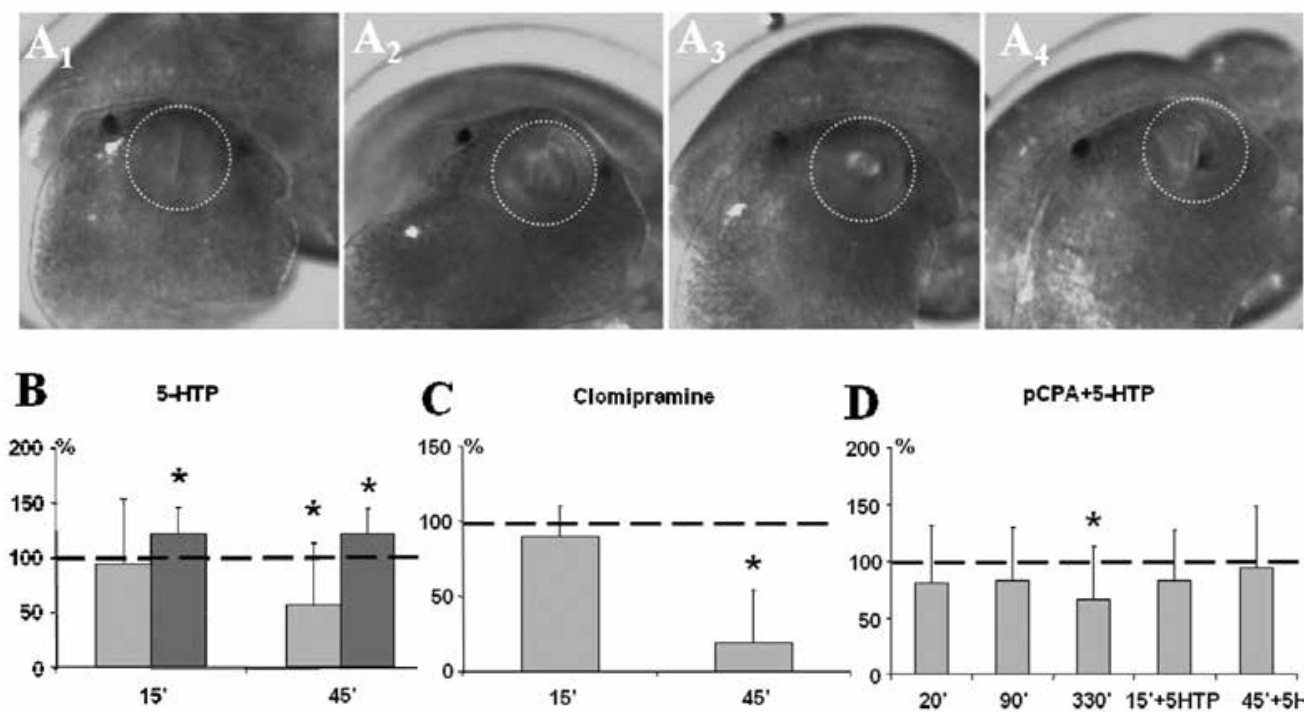

C Clomipramine

D $\mathrm{PCPA}+5+\mathrm{HTP}$
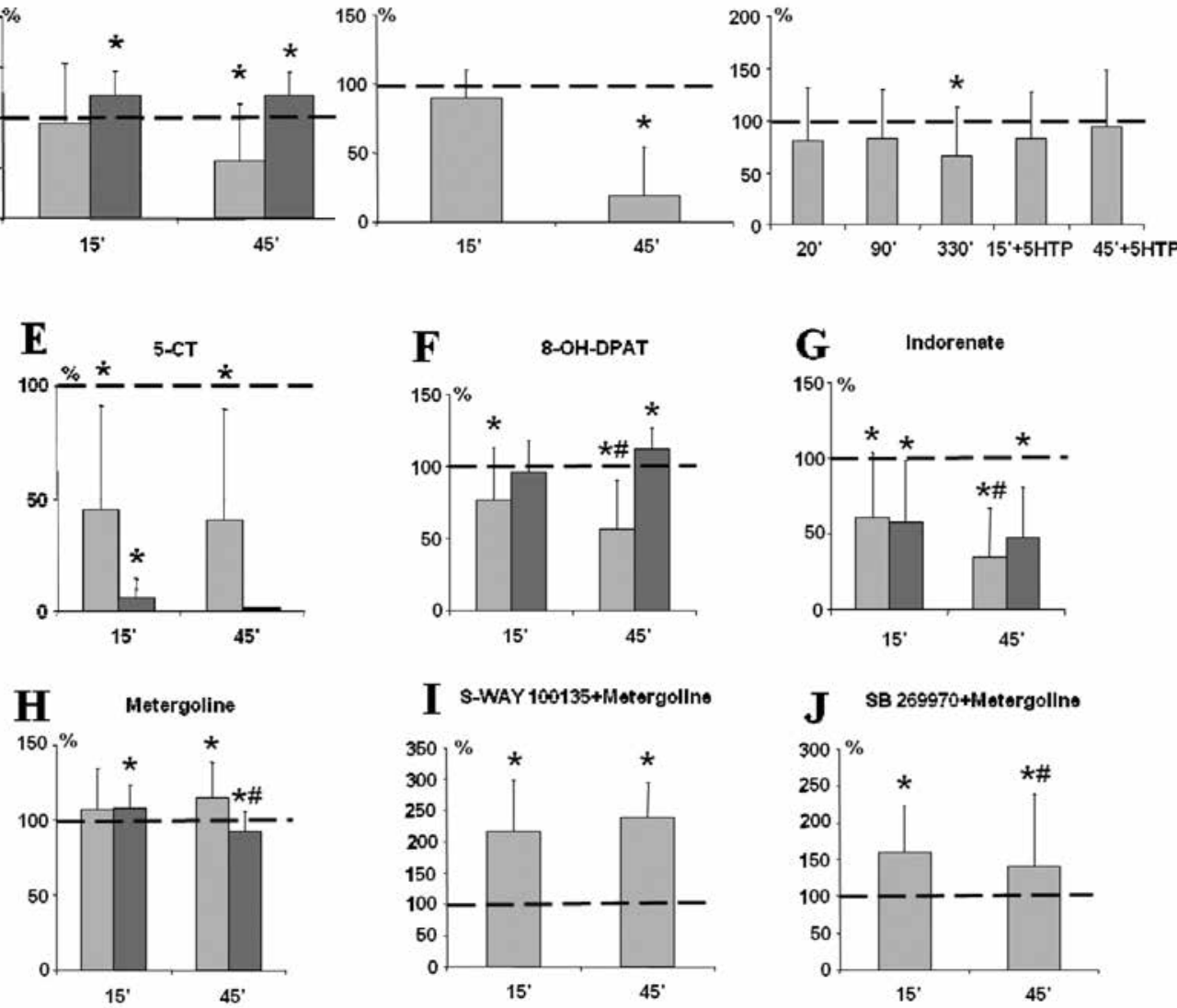
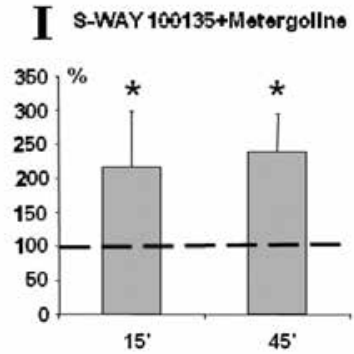

J SB 269970+Metergollne

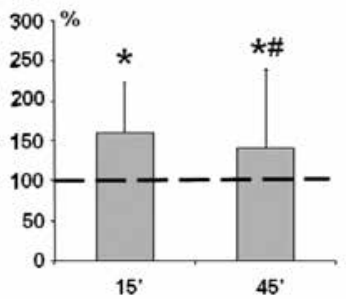


Fig. 2. Pharmacological analysis of the 5-HTergic regulation of feeding rhythm in Lymnaea at $100 \%$ stage of development. (A) Time-laps frames demonstrating various phases of the radula movement in living embryos. $\mathrm{A}_{1}$ mouth closed, $\mathrm{A}_{2}$ : radula protraction, $\mathrm{A}_{3}$ : rasping and $\mathrm{A}_{4}$ : radula retraction. The mouth region is encircled. (B-J) Effects of 5-HTergic drugs on the feeding activity (frequency of the radula protrusion normalized to the control). Light grey columns represent the lower and dark grey columns represent the higher concentration of the applied drugs. (B) 5-HTP modulates the feeding activity in two different ways, depending on the applied concentration. Ten $\mu \mathrm{M} 5$-HTP decreases the number of radula protrusions after 45 minutes incubation, whereas $100 \mu \mathrm{M}$ increases it. (C) $5 \mu \mathrm{M}$ clomipramine decreases significantly the number of rasping after $45 \mathrm{~min}$. (D) The long-lasting inhibitory effect of pCPA is rescued by the administration of $100 \mu \mathrm{M} 5$-HTP. (E) 5-CT has a strong concentration-dependent inhibitory effect. Note the complete block of the feeding activity after 45 minutes after $0.5 \mu \mathrm{M}$ application. (F) 8-OH-DPAT decreases the buccal rhythm at $0.1 \mu \mathrm{M}$ concentration, while at $1 \mu \mathrm{M}$ it has a slightly enhancing effect. (G) Indorenate applied at 0.5 and $2 \mu \mathrm{M}$ concentrations decreases the number of the protractions significantly both after 15 and $45 \mathrm{~min}$ of application. (H) $0.5 \mu \mathrm{M}$ metergoline slightly increases the feeding activity, meanwhile at $5 \mu \mathrm{M}$ concentration it induces an increase after $15 \mathrm{~min}$, followed then by a slight decrease after $45 \mathrm{~min}$. (I) The combined application of S-WAY $100135(1 \mu \mathrm{M})$ and metergoline $(0.5 \mu \mathrm{M})$ resulted in a more than twofold increase of the frequency of radula protractions. Note the long-lasting effect. (J) Combined application of SB269970 $(1 \mu \mathrm{M})$ and metergoline $(0.5 \mu \mathrm{M})$ leads to a long-lasting activating effect. *Statistically significant difference $(\mathrm{p}<0.001)$ from the control. \#Statistically significant difference from the previous time interval

radula protractions after $45 \mathrm{~min}$ (Fig. 2C). Incubation with the 5-HT synthesis blocker, pCPA $(5 \mu \mathrm{M})$ resulted in the gradual decline of the number of protractions (up to $65 \%$ after 330 min, $\mathrm{n}=11$ ), meanwhile adding $100 \mu \mathrm{M} 5$-HTP completely rescued this effect after $45 \mathrm{~min}$ (Fig. 2D).

5-CT, a 5- $\mathrm{HT}_{1,5,7}$ receptor agonist, caused a significant decrease $(44 \%, \mathrm{n}=11)$ of the radula protrusions already at low $(0.1 \mu \mathrm{M})$ concentration after $15 \mathrm{~min}$. At higher $(0.5 \mu \mathrm{M})$ concentration, 5 -CT totally blocked $(\mathrm{n}=24)$ the buccal rhythm after $45 \mathrm{~min}$ (Fig. 2E). 8-OH-DPAT, a 5-HT 1,7 receptor agonist, induced a significant but gradual decrease of the number of rasping at $0.1 \mu \mathrm{M}$ concentration (up to $77 \%$ after $15 \mathrm{~min}$ and $56 \%$ after $45 \mathrm{~min}, \mathrm{n}=21)$. In contrast, at $1 \mu \mathrm{M}$ concentration $(\mathrm{n}=9)$ this agonist had no significant effect after $15 \mathrm{~min}$ of incubation, but evoked a slight increase of the feeding rhythm after $45 \mathrm{~min}$ of application (Fig. 2F). Indorenate, a 5-HT 1 receptor agonist, significantly reduced the protraction rate in a time-dependent manner at both $0.5(\mathrm{n}=5)$ and $2 \mu \mathrm{M}$ concentrations $(\mathrm{n}=5)($ Fig. $2 \mathrm{G})$. Low $(1 \mu \mathrm{M})$ concentration of metergoline, which is a $5-\mathrm{HT}_{6,7}$ receptor agonist and a $5-\mathrm{HT}_{1}$ receptor antagonist, resulted in a slight increase of the buccal mass activity (up to 7\% after $15 \mathrm{~min}$ and $15 \%$ after $45 \mathrm{~min}, \mathrm{n}=17$ in both cases), whereas at $5 \mu \mathrm{M}$ concentration it increased $(7 \%, \mathrm{n}=10)$ the rasping after $15 \mathrm{~min}$, but decreased $(8 \%, \mathrm{n}=10)$ it after $45 \mathrm{~min}$ (Fig. $2 \mathrm{H})$. The application of 5-HT 6 receptor antagonist, SB258585 $(1 \mu \mathrm{M})$ failed to block the activating effect of metergoline $(n=23)$ (data not shown). 
While the $5-\mathrm{HT}_{1}$ receptor antagonist, S-WAY 100135 or the $5-\mathrm{HT}_{7}$ receptor antagonist, SB269970 alone had no effect on the buccal activity at any concentrations tested $(0.1-1 \mu \mathrm{M})$ either after $15 \mathrm{~min}$ or $45 \mathrm{~min}$ (data not shown), their combined application with metergoline produced the strongest and most specific stimulatory action on the buccal rhythm of $100 \%$ stage embryos. Application of S-WAY 100135 $(1 \mu \mathrm{M})$ or metergoline $(0.5 \mu \mathrm{M})$ led to a more than a twofold increase in the radula protrusion (up to $216 \%$ and $238 \%$ ) after $15 \mathrm{~min}$ and $45 \mathrm{~min}$, respectively $(\mathrm{n}=11$ ) (Fig. 2I). Application of SB269970 $(1 \mu \mathrm{M})$ and metergoline $(0.5 \mu \mathrm{M})$ increased the number of radula protrusions by $159 \%$ and $141 \%$ both after $15 \mathrm{~min}$ and $45 \mathrm{~min}$ $(\mathrm{n}=23)$ (Fig. 2J).

\section{Characterization of 5-HT receptors in the buccal muscle}

\section{$\left[{ }^{3} H\right]-5-H T$ binding in the buccal muscle membrane}

To determine the kinetic parameters of 5-HT receptors in the buccal mass, receptor binding was analyzed with various concentrations of $\left[{ }^{3} \mathrm{H}\right]-5-\mathrm{HT}$ in membrane pellets obtained from the buccal mass of P5-P6 juvenile snails (Fig. 3A). The kinetic analysis of the saturation curve revealed a $\mathrm{K}_{\mathrm{d}}$ value of $4.5 \mathrm{nM}$ and a $\mathrm{B}_{\max }$ value of $2.4 \mathrm{fmol} /$ $\mathrm{mg}$, respectively. The Scatchard-plot of the saturation curve indicated a single high affinity 5-HT binding site.

Inhibition of $\left[{ }^{3} \mathrm{H}\right]-5-\mathrm{HT}$ binding by agonists (5-HT, 5-CT) and antagonists (doxepine, SB258585) showed that 5-HT inhibited the binding already at lower concentration, meanwhile 5-CT had a low affinity to the 5-HT receptor, inhibiting the binding only at higher concentration. The $5-\mathrm{HT}_{6}$ receptor antagonists displayed a moderate affinity to the receptor, inhibiting the binding at higher concentration than 5-HT (Fig. 3B).

\section{Changes of the adenylate cyclase activity after pharmacological intervantions}

Following the incubation of the buccal mass with 5-HT and its agonists (5-CT, 8-OH-DPAT, 5-metoxytriptamine), the cAMP level was increased as a result of the stimulation of adenylate cyclase (Fig. 3C). 5-HT influenced the cAMP level more effectively than the agonists and the rank order potency was 5-HT $>5$-metoxytryptamine $>5$-CT $>8$-OH-DPAT. When $5-\mathrm{HT}_{6}$ receptor antagonists (SB252585, clozapine) or re-uptale inhibitors (clomipramine, doxepine) were applied, the 5-HT stimulated adenylate cyclase activity decreased, and the rank order potency was SB252585 > clozapine $>$ doxepine $>$ clomipramine (Fig. 3D). 

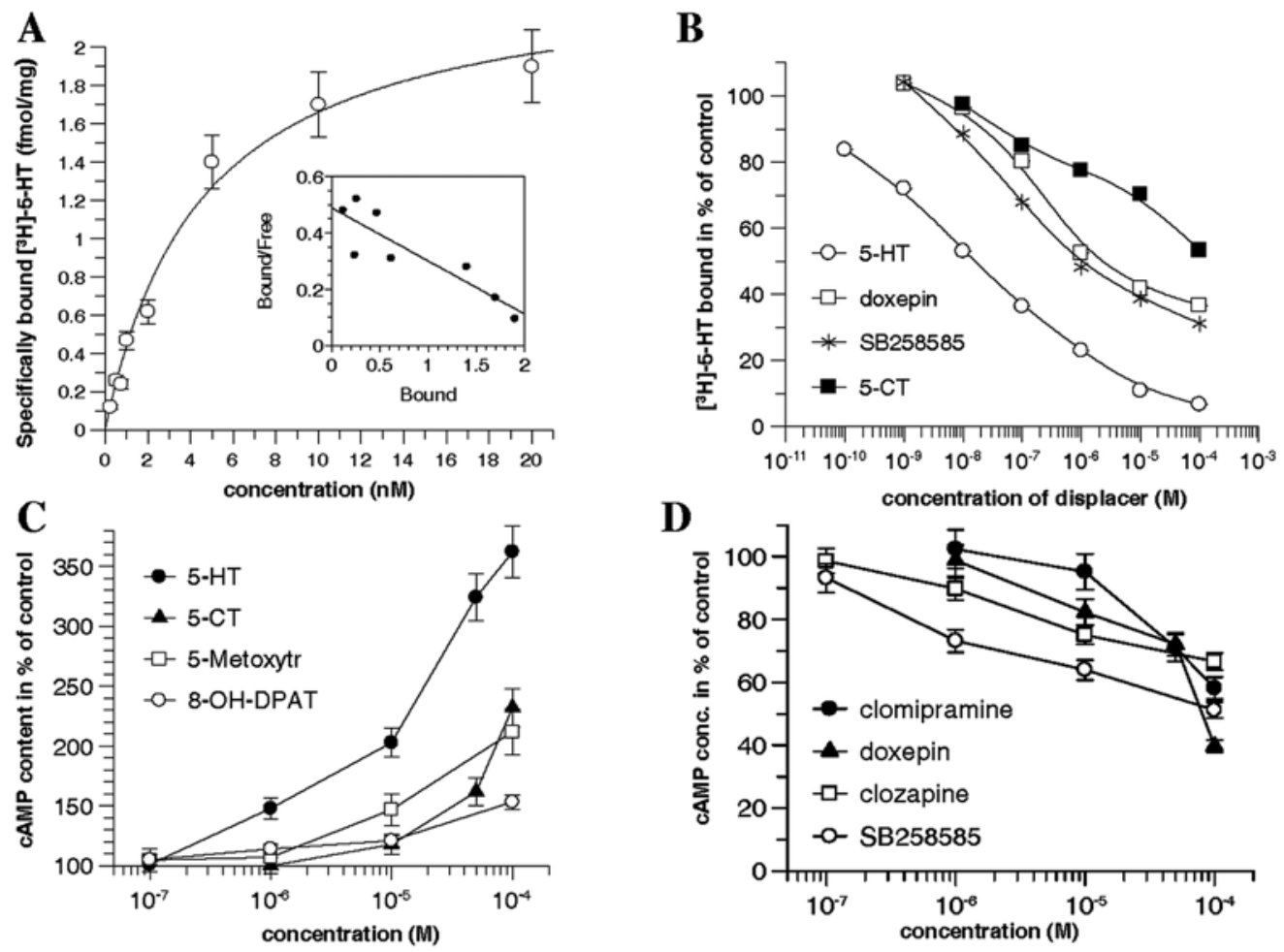

Fig. 3. Characterization of the 5-HT receptors in membrane preparations obtained from the buccal mass of P5-P6 Lymnaea. (A) Binding of [ $\left.{ }^{3} \mathrm{H}\right]-5-\mathrm{HT}$ to 5-HT receptor. The binding shows saturation and the kinetic analysis of the curve reveals a $K_{d}$ and $B_{\max }$ values of $4.5 \mathrm{nM}$ and $2.4 \mathrm{fmol} / \mathrm{mg}$, respectively. The Scatchard plot of the saturation curve (insert) indicates a single high affinity 5-HT binding site. (B) Inhibition of [ $\left.{ }^{3} \mathrm{H}\right]-5-\mathrm{HT}$ binding by agonists (5-HT, 5-CT) and antagonists (Doxeprine, SB258585). The data represent the mean percent of the maximum specific binding measured in parallel and repeated three times. The SEM values were less than $10 \%$. (C) Adenylate cyclase stimulation with 5-HT or 5-HT agonists. The enhanced adenylate cyclase activity detected corresponds to the increased cAMP level. 5-HT is the most effective, followed by 5-methoxytriptamine, 5-CT and 8-OH-DPAT. The data are means \pm SEM. (D) Inhibition of 5-HT $(100 \mu \mathrm{M})$ stimulated adenylate cyclase activity by different $5-\mathrm{HT}_{6}$ receptor antagonists (SB252585 and clozapine) and antidepressants (clomipramine and doxepine). The data are means \pm SEM

\section{DISCUSSION}

In the present study, with the help of combining the results of IHC, biochemical and pharmacological-physiological experiments, we have delivered data supporting, with until yet unknown details, the role of 5-HT in the regulation of feeding activity (radula protrusion) of the pond snail, Lymnaea stagnalis. Earlier and recent studies performed on the embryonic Lymnaea and related species, such as Helisoma, have already delivered a broad palette of results reporting on the development of the 
5-HTergic system, including the distribution and sequence of appearance of 5-HT-IR elements both at central and peripheral levels [4, 34, 54], as well as the role of 5-HT in the regulation of early embryonic behaviors, such as rotation and gliding [15, 22], either by receptor characterization or pharmacological manipulation (pCPA administration) of the 5-HT level. However, an extensive analysis of the 5-HTergic regulation of the feeding behavior has not yet been performed, including the complex, quantitative immunohistochemical and pharmacological investigation of the 5-HTergic maturation of this behavior. Regarding this, the novelties of our study can be summarized as follows.

(i) Quantitative IHC findings proved that the 5-HT containing elements innervating the buccal mass (muscle system) and so being possibly involved for the execution of feeding activity are indeed 5-HTergic because they display parallel changes of fluorescence intensity with the direction of the pharmacological manipulation of their transmitter content measured by HPLC assay. Namely, following 5-HTP administration an increased whereas after pCPA treatment a decreased immunofluorescence intensity could be observed, supported also by quantitative immunohistohemical measuments. According to an earlier qualitative assay, 5-HT immunofluorescence labeling was shown to completely disappear following pCPA administration both in $60 \%$ and $85 \%$ Lymnaea embryos [15]. The only source of this 5-HTergic fibers in gastropods is the giant cerebral neuron (CGC/MGC) that sends peripheral processes to the head region [27, 38]; Elekes, unpublished; see also [8], about which series of earlier and recent studies reported to fulfill a key role in modulating the feeding activity [12, 62, 63]; see also [18]. In contrast, data were missing until our present study reporting about the direct peripheral effect of 5-HT on the feeding activity (buccal rhythm/radula protrusion).

(ii) Our results demonstrate that while lowering the 5-HT level evokes the reduction of the buccal rhythm, its enhancement does not result in the activation of the feeding activity, only when applying a higher concentration $(100 \mu \mathrm{M})$ of the precursor, 5-HTP. The results corresponds to earlier observations obtained on Lymnaea embryos following 5-HT application [15], and supports further the role of 5-HT in the regulation of the buccal rhythm.

(iii) Attempts to identify receptors involved in the 5-HTergic regulation of different embryonic behaviors of Lymnaea were already made by Filla et al. [15] and Hiripi and Elekes [25]. It was demonstrated that a 5- $\mathrm{HT}_{1}$-like receptor subtype is involved in the regulation of rotation and gliding, whereas the identification of any 5-HT-like receptor regulating radula protraction has failed. Earlier, a $5-\mathrm{HT}_{1}$ receptor subtype was demonstrated in Helisoma embryos that was responsible for the ciliary (rotation) movement [22]. Early cloning experiments revealed two different 5-HT receptor types in the Lymanea CNS (5-HT 1 Lym, [48]; 5- $\mathrm{HT}_{2 \mathrm{Lym}}$, [17]. Our present pharmacological analysis to characterize 5-HT receptors contributing to the modulatory action of 5-HT suggests that 5-HT can exert an inhibitory action via 5- $\mathrm{HT}_{1}$ receptors and an excitatory effect via 5- $\mathrm{HT}_{6,7}$ receptors. According to the in vivo pharmacologicalphysiological experiments, effect of clomipramine confirmed the role of a 5- $\mathrm{HT}_{6}$ receptor in the muscle activity. The involvement of additional 5-HT receptor types 
other than the $5-\mathrm{HT}_{6}$ can be suggested in the regulation of feeding activity (radula protrusion). These receptors would be the $5-\mathrm{HT}_{1}$ and the $5-\mathrm{HT}_{7}$ receptors. The presence of a $5-\mathrm{HT}_{1}$ receptor type is supported by the effect of 5-CT. According to our findings, radula protrusion of $100 \%$ stage embryos, displaying already the adult-like feeding activity, was stimulated by 5-HT (synthetized following the application of the precursor 5-HTP) and metergoline, an antagonist of 5- $\mathrm{HT}_{1}$ receptor, and the agonist of $5-\mathrm{HT}_{6,7}$ receptor, but was inhibited by the 5- $\mathrm{HT}_{1,5,7}$ receptor agonist, 5-CT. Combining the application of the 5- $\mathrm{HT}_{1}$ receptor antagonist, S-WAY 100135 with metergoline caused a significant $(200 \%)$ increase of the number of radula protrusions already after 15 minutes, indicating the blockage of the $5-\mathrm{HT}_{1}$ receptor, and the parallel stimulation of the $5-\mathrm{HT}_{6,7}$ receptor. Indorenate, a 5- $\mathrm{HT}_{1}$ receptor agonist also decreased the rate of radula protraction, indicating a negative AC coupling. The identification of the excitatory and inhibitory 5-HT receptors in the buccal rhythm regulation of Lymnaea seems to be an a priori finding, since yet data have not been reported providing evidence on the direct peripheral involvement of this monoamine in feeding. In an earlier study on the possible role of monoamines (5-HT, DA) in the regulation of different embryonic behaviors, Filla et al. [15] have shown the involvement of a $5-\mathrm{HT}_{1}$-like receptor, similar to that of the vertebrate type, in the regulation of both rotation and gliding, whereas the identification of a 5-HTergic receptor in the radula movement remained to be cleared. Later, based on pharmacological and biochemical assays, Hiripi and Elekes [25] delivered evidences for the unequivocal role of a $5-\mathrm{HT}_{1 \mathrm{~A}}$ receptor of vertebrate type in the regulation of the cilia driven rotation of early Lymnaea embryos. A 5-HT 1 receptor type was also demonstrated following different pharmacological interventions in Helisoma embryos by Goldberg et al. [22], coupled to early ciliary driven rotation, although Filla et al. [15] have questioned the validity of the results.

(iv) The presence of a 5- $\mathrm{HT}_{6}$ type receptor in the buccal mass was also confirmed by binding experiments performed on membrane pellets, showing the displacement of the high affinity binding of [ $\left.{ }^{3} \mathrm{H}\right]-5-\mathrm{HT}$ by the same 5-HTergic agonists and antagonists which were also applied in the cAMP experiments. Also, 5-HT and other agonists stimulated adenylate cyclase activity, indicating the positive coupling of the enzyme to the $5-\mathrm{HT}_{6}$ receptor. It is, however, to be noted that these experiments were carried out on intact but dissected buccal complex preparations, while the physiological experiments were performed on in vivo snail embryos.

(v) 5-HT was shown to stimulate adenylate cyclase activity in the buccal mass, indicating the presence of a 5-HT receptor positively coupled to cAMP. The pharmacological profile of the 5-HT receptor characterized following the cAMP experiments suggests that it is a 5 - $\mathrm{HT}_{6}$-like type, since 5-HT and 5-metoxytryptamine stimulated more effectively the adenylate cyclase activity, than 5-CT and 8-OH-DPAT, and $5-\mathrm{HT}_{6}$ receptor antagonists such as SB252585, clozapine, clomipramine and doxepine decreased the adenylate cyclase activity.

In summary, the physiological-pharmacological results suggest that three 5-HT receptors, the inhibitory 5 - $\mathrm{HT}_{1}$-like and the stimulatory $5-\mathrm{HT}_{6,7}-$ like receptors are involved in the 5-HTergic regulation of buccal rhythm (radula protraction). In 
Helisoma embryos, the 5-HTergic driven ciliary rotation was regulated through a $5-\mathrm{HT}_{1}$ and a 5- $\mathrm{HT}_{7}$ receptor [33], meanwhile in Lymnaea the 5- $\mathrm{HT}_{1 \mathrm{~A}}$ receptor was shown to be involved in this early form of embryonic behavior [25]. In adult gastropod mollusks, five 5-HT receptor genes have been cloned: two in the pond snail, Lymnaea stagnalis [17, 48] and three in Aplysia californica [2, 32]. When interpreting our present findings obtained on 5-HT receptors, it is to be taken into account that although the endogenous receptors are often classified according to the mammalianbased categories, in many cases the pharmacological properties of vertebrate and invertebrate receptors differ significantly and the unequivocal identity of the latter is questionable $[25,52,58]$.

\section{ACKNOWLEDGEMENTS}

Supported by the grants of Hungarian Scientific Research Fund (OTKA), K78224 and K111990 (K. E), the Russian Science Foundation, 17-14-01353 (E.E.V.), and an exchange program between the Hungarian and the Russian Academy of Sciences (I.B., G.B. and E.E.V.). The skillful technical assistance of Ms. Zsuzsanna N. Fekete, Ms. Katalin E. Ihász and Mr. Boldizsár Balázs is greatly acknowledged.

\section{REFERENCES}

1. Alekseyenko, O. V., Lee, C., Kravitz, E. A. (2010) Targeted manipulation of serotonergic neurotransmission affects the escalation of aggression in adult male Drosophila melanogaster. PLoS 24;5(5), e10806.

2. Angers, A., Storozhuk, M. V., Duchaine, T., Castellucci, V. F., DesGroseillers, L. (1998) Cloning and functional expression of an Aplysia 5-HT receptor negatively coupled to adenylate cyclase. J. Neurosci. 18, 5586-5593.

3. Balaban, P. M., Vehovszky, Á., Maksimova, O. A., Zakharov, I. S. (1987) Effect of 5,7-dihydroxytryptamine on food-aversion conditioning in the snail Helix lucorum. Brain Res. 404, 201-210.

4. Balog, G., Voronezhskaya, E. E., Hiripi, L., Elekes, K. (2012) Organization of the serotonergic innervation of the feeding (buccal) musculature during the maturation of the pond snail Lymnaea stagnalis: A morphological, biochemical and physiological study. J. Comp. Neurol. 520, 315-329.

5. Baumgarten, H. G., Göthert, M. (2000) Serotoninergic neurons and 5-HT receptors in the CNS. Springer, Berlin-Heidelberg.

6. Benjamin, P. R. (2012) Distributed network organization underlying feeding behavior in the mollusk Lymnaea. Neural. Syst. Circuits 2, 4.

7. Burrows, M. (1996) The neurobiology of an insect brain. University Press, Oxford-New YorkTokyo-Oxford.

8. Chase, R. (2002) Behavior and its neural control in gastropod mollusks. Oxford Univ. Press, New York.

9. Croll, R. P., Chiasson, B. J. (1989) Postembryonic development of serotoninlike immunoreactivity in the central nervous system of the snail, Lymnaea stagnalis. J, Comp, Neurol. 280, 122-142.

10. Edwards, D. H., Kravitz, E. A. (1997) Serotonin, social status and aggression. Curr. Opin. Neurobiol. 7, 812-819.

11. Elliot, C. J. H., Benjamin, P. R. (1985) Interactions of pattern generating interneurons controlling feeding in Lymnaea stagnalis. J. Neurophysiol. 54, 1396-1411.

12. Elliot, C. J. H., Benjamin, P. R. (1985) Interaction of the slow oscillator interneuron with feeding pattern generating interneurons in Lymnaea stagnalis. J. Neurophysiol. 54, 1412-1421. 
13. Elliot, C. J. H., Vehovszky, Á. (2000) Comparative pharmacology of feeding in molluscs. Acta Biol. Hung. 51, 153-163.

14. Elliott, C. J. H., Susswein, A. J. (2002) Comparative neuroethology of feeding control in molluscs. J. Exp. Biol. 205, 877-896.

15. Filla, A., Hiripi, L., Elekes, K. (2009) Role of the aminergic (serotonin and dopamine) systems in the embryogenesis and different embryonic behaviors of the pond snail, Lymnaea stagnalis. Comp. Biochem. Physiol. C 149, 73-82.

16. Gaddum, J. H., Picarelli, Z. P. (1957) Two kinds of tryptamine receptor. Br. J. Pharmacol. 12, 323328.

17. Gerhardt, C. C., Leysen, J. E., Planta, R. J., Vreugdenhil, E., Van Heerikhuizen, H. (1996) Functional characterization of a 5- $\mathrm{HT}_{2}$ receptor cDNA cloned from a Lymnaea stagnalis. Eur. J. Pharmacol. 311, 249-258.

18. Gillette, R. (2006) Evolution and function in serotonergic systems. Integr. Comp. Biol. 46, 838-846.

19. Glanzman, D. L. (2007) Simple minds: The neurobiology of invertebrate learning and memory. In: North, G., Greenspan, R. J. (eds) Invertebrate neurobiology. Cold Spring Harbor Laboratory Press, Cold Spring Harbor, New York, pp. 347-380.

20. Glanzman, D. L., Mackey, S. L., Hawkins, R. D., Dyke, A. M., Lloyd, P. E., Kandel, E. R. (1989) Depletion of serotonin in the nervous system of Aplysia reduces the behavioral enhancement of gill withdrawal as well as the heterosynaptic facilitation produced by tail shock. J. Neurosci. 9, 42004213.

21. Goaillard, J. M., Taylor, A. L., Schulz, D. J., Marder, E. (2009) Functional consequences of animalto-animal variation in circuit parameters. Nature Neurosci.12, 1424-1430.

22. Goldberg, J. I., Koehncke, N. I., Christopher, K. J., Neurmann, C., Diefenbach, T. J. (1994) Pharmacological characterization of a serotonin receptor involved in an early embryonic behavior of Helisoma trivolvis. J. Neurobiol. 25, 1545-1557.

23. Hawkins, R. D., Kandel, E. R., Bailey, C. H. (2006) Molecular mechanisms of memory storage in Aplysia. Biol, Bull. 210, 174-191.

24. Hernádi, L., Elekes, K., S.-Rózsa. K. (1989) Serotonin-containing neurons in the central nervous system of the snail Helix pomatia. Comparison of immunocytochemical and 5,6-dihydroxytryptamine-labelling. Cell Tissue Res. 257, 313-323.

25. Hiripi, L., Elekes, K. (2010) A 5- $\mathrm{HT}_{1 \mathrm{~A}}$-like receptor is involved in the regulation of the embryonic rotation of Lymnaea stagnalis. Comp. Biochem. Physiol. Part C 152, 57-61.

26. Kemenes, G., Benjamin, P. R. (1989) Appetitive learning in snails show the characteristics of conditioning in vertebrates. Brain Res. 489, 163-166.

27. Kemenes, G., Elekes, K., Hiripi, L., Benjamin, P. R. (1989) A comparison of four techniques for mapping the distribution of serotonin and serotonin-containing neurons in fixed and living ganglia of the snail, Lymnaea. J. Neurocytol. 18, 193-208.

28. Kiss, T., Hernádi, L., László, Z., N. Fekete, Zs., Elekes, K. (2010) Peptidergic modulation of serotonin and nerve elicited responses of the salivary duct musculature in the snail, Helix pomatia. Peptides 31 , $1007-1018$.

29. Kupferman, I., Cohen, J. L., Mandelbaum, D. E., Schonberg, M., Susswein, A. J., Weiss, K. R. (1979) Functional role of serotonergic neuromodulation of Aplysia. Fed. Proc. 38, 2095-2102.

30. Kuslansky, B., Weiss, K. R., Kupfermann, I. (1987) Mechanism underlying satiation of feeding behaviour of the mollusk, Aplysia. Behav. Neural. Biol. 48, 278-303.

31. Leatherbarrow, R. J. (1992) GraFit version 3.0. Staines, United Kingdom Erathicus Software Ltd.

32. Li, X.-C., Giot, J.-F., Kuhl, D., Hen, R., Kandel, E. R. (1995) Cloning and characterization of two related serotonergic receptors from the brain and the reproductive system of Aplysia that activate phopholipase C. J. Neurosci. 15, 7585-7591.

33. Mapara, S., Parries, S., Quarrington, C., Ahn, K. C., Gallin, W. J., Goldberg, J. I. (2008) Identification, molecular structure and expression of two cloned serotonin receptors from the pond snail, Helisoma trivolvis. J. Exp. Biol. 211, 900-910. 
34. Marois, R., Croll, R. P. (1992) Development of serotonergic cells within the embryonic central nervous system of the pond snail, Lymnaea stagnalis. J, Comp. Neurol. 322, 255-265.

35. Menzel, R., Müller, U. (1997) Learning and memory in honeybees. From behavior to neural substrates. Annu. Rev. Neurosci. 19, 379-404.

36. Mescheriakov, V. N. (1990) The common pond snail, Lymnaea stagnalis L. In: Detlaff, D. A., Vassetzky, S. G. (eds) Animal species for developments studies. Plenum Press, New York, pp. 69-132.

37. Morrill, J. B. (1982) Development of the pulmonate gastropod, Lymnaea. In: Harrison, F. W., Cowden, R. R. (eds) Developmental biology of the freshwater invertebrates. Alan R. Liss. New York, pp. 399-483.

38. Pentreath, V. W., Cottrell, G. A. (1974) Anatomy of an identified serotonin neurone studied by means of injection of tritiated 'transmitter'. Nature 250, 655-658.

39. Pentreath, V. W., Berry, M. S., Osborne, N. N. (1982) The serotonergic cerebral cells in gastropods In: Osborne, N. N. (ed.), Biology of serotonergic transmission. Wiley, New York. pp. 457-513.

40. Rehm, K. J., Deeg, K. E., Marder, E. (2008) Developmental regulation of neuromodulator function in the stomatogastric ganglion of the lobster, Homarus americanus. J. Neurosci. 28, 9828-9839.

41. Rosen, S. C., Weiss, K. R., Cohen, J. L., Kupfermann, I. (1982) Interganglionoc cerebral-buccal mechanoafferents of Aplysia: receptive fields and synaptic connections to different classics of neurons involved in feeding behaviour. J. Neurophysiol. 48, 271-288.

42. Roth, B. L. (2006) The serotonin receptors. Humana, Totowa, New Jersey.

43. S.-Rózsa, K. (1984) The pharmacology of molluscan neurons. Progr. Neurobiol. 23, 79-150

44. Sakharov, D. A. (1976) Nerve cell homologies in gastropods. In: Salánki, J. (ed.) Neurobiology of invertebrates. Gastropod brain. Akadémiai Kiadó, Budapest, pp. 27-40.

45. Schindelin, J., Arganda-Carreras, I., Frise, E., Kaynig, V., Longair, M., Pietzsch, T., Preibisch, S., Rueden, C., Saalfeld, S., Schmid, B., Tinevez, J. Y., White, D. J., Hartenstein, V., Eliceiri, K., Tomancak, P., Cardona, A. (2012) Fiji: an open-source platform for biological-image analysis. Nat. Methods 9, 676-682.

47. Selverstone, I., Moulins, M. (1987) The crustacean stomatogastric system. Springer, Berlin.

48. Sugamori, K. S., Sunahara, R. X., Guan, H.-C. (1993) Serotonin receptor cDNY, cloned from Lymnaea stagnalis. Proc. Natl. Acad. Sci. USA 90, 11-15.

49. Susswein, A. J., Byrne, J. H. (1988) Identification and characterization of the neurons initiating patterned neural activity in the buccal ganglia of Aplysia. J. Neurosci. 8, 2049-2061.

50. Syed, N. I., Winlow, W. (1991) Respiratory behavior in the pond snail Lymnaea stagnalis. II. Neural elements of the central pattern generator (CPG). J. Comp. Physiol. A 169, 557-568.

51. Syed, N. I., Winlow, W. (1991) Coordination of locomotor and cardiorespiratory networks of Lymnaea stagnalis by a pair of identified interneurons. J. Exp. Biol. 158, 37-62.

52. Tierney, A. J. (2001) Structure and function of invertebrate 5-HT receptors: a review. Comp. Biochem. Physiol. - Part A: Mol. Integ. Physiol. 128, 791-804.

53. Vleugels, R., Verlinden, H., Vanden Broeck, J. (2015) Serotonin, serotonin receptors and their actions in insects. Neurotransmitter 2, e314.

54. Voronezhskaya, E. E., Elekes, K. (1993) Distribution of serotonin-like immunoreactive neurons in the embryonic nervous system of Lymnaea and planWWW snails, Neurobiology (Budapest) 1, 371-383.

55. Voronezhskaya, E. E., Hiripi, L., Elekes, K., Croll, R. P. (1999) Development of catecholaminergic neurons in the pond snail, Lymnaea stagnalis: I. Embryonic development of dopamine-containing neurons and dopamine-dependent behaviors. J. Comp. Neurol. 404, 285-296.

56. Voronezhskaya, E. E., Khabarova, M. Y., Nezlin, L. P. (2004) Apical sensory neurones mediate developmental retardation induced by conspecific environmental stimuli in freshwater pulmonate snails Development 131, 3671-3680.

57. Walker, R. J. (1985) The pharmacology of serotonin receptors in invertebrates. In: Green, A. R. (ed.) Neuropharmacology of serotonin. Oxford Univ. Press, Oxford, pp. 366-408.

58. Walker, R. J., Brooks, H. I., Holden-Dye, L. (1996) Evolution and overview of classical transmitter molecules and their receptors. Parasitology 113, S3-S33. 
59. Weiss, K., Kupfermann, I. (1976) I. Homology of the giant serotonergic neurons 59. (metacerebral cells) in Aplysia and other pulmonate mollusks. Brain Res. 117, 33-49.

60. Weiss, K. R., Cohen, J. L., Kupfermann, I. (1978) Modulatory control of buccal musculature by a serotonergic neuron (metacerebral cell) in Aplysia. J. Neurophysiol. 41, 181-203.

61. Wu, W.-H., Cooper, R. L. (2012) Serotonin and synaptic transmission at invertebrate neuromuscular junctions. Exp. Neurobiol. 21, 101-112.

62. Yeoman, M. S., Brierley, M., Benjamin, P. R. (1996) Central pattern generator interneurons are targets for the modulatory serotonergic cerebral giant cell in the feeding system of Lymnaea. J. Neurophysiol. $75,11-25$.

63. Yeoman, M. S., Kemenes, G., Benjamin, P. R., Elliott, C. J. (1994) Modulatory role for the serotonergic cerebral giant cells in the feeding system of the snail, Lymnaea. II. Photoinactivation. J. Neurophysiol. 72, 1372-1381. 